\title{
KRYPTOMĚNY A OBČANSKÉ PRÁVO
}

\author{
ADAM JARE $\check{S}^{1}$
}

\begin{abstract}
ABSTRAKT
Kryptoměny nejsou v současné chvíli v oblasti soukromého práva jakkoliv výslovně upraveny a jejich regulaci je možné nalézt pouze ve veřejnoprávních předpisech. Cílem textu je posouzení, jakým zpưsobem na kryptoměny nahlíží občanský zákoník, jaké právní vztahy vznikají při zápisu transakce do nového bloku v rámci protokolu blockchain a zda lze považovat kryptoměny za věc ve smyslu její legální definice v občanském zákoníku. Text se následně věnuje diskuzi o důsledcích dosažených závěrů.
\end{abstract}

\section{KLÍČOVÁ SLOVA}

blockchain, kryptoměny, bitcoin, občanský zákoník, věc v právním smyslu, nabídka a akceptace, transakce

\begin{abstract}
Cryptocurrencies are not currently regulated by civil law and it is possible to find their regulation only in public law. The main aim of this text is to examine how the Civil Code can deal with cryptocurrencies, what legal relationships arise when a transaction is included into a new block within a blockchain protocol, and whether cryptocurrencies could be regarded as a "thing" in a legal sense within the meaning of its legal definition in the Civil Code. Text then focuses on a discussion about consequences of the author's conclusions.
\end{abstract}

1 Mgr. Adam Jareš, doktorand katedry občanského práva Fakulty právnické ZČU, kontaktní e-mail: ajares@kpo.zcu.cz 


\section{KEYWORDS}

blockchain, cryptocurrencies, bitcoin, civil code, thing in a legal sense, offer and acceptance, transactions

\section{1. ÚVOD}

Vývoj v oblasti elektronické kontraktace a transakcí je dotčen fenoménem virtualizace, který se ostatně projevuje v celém oboru práva informačních technologií. $^{2}$ Jeho projevem je také protokol blockchain, jehož prostřednictvím jsou provozovány kryptoměny jako určitá alternativa k tzv. fiat měnám, tedy měnám s nuceným oběhem. Jejich fungování má nejen technologické a ekonomické konotace, ale i ty právní, kterým je věnován tento text, jenž na kryptoměny nahlíží optikou zákona č. 89/2012 Sb., občanský zákoník, ve znění pozdějších předpisů (dále jen „obč. zák.“).

Důkazem toho, že se kryptoměny skutečně dostávají do zájmu širší veřejnosti, může být i skutečnost, že se jim postupně dostává pozornosti i v textech, které nejsou určeny pouze technologickým nadšencům či investorům a spekulantům. Příkladem může být článek Deníku $\mathrm{N}$, který se věnuje desetiletému výročí kryptoměny bitcoin. Ten začíná následujícím textem: „Potíž s bitcoinem spočívá v tom, že to není věc, ale př́běh. Není to vlastně technický ani ekonomický fenomén, jeho popis a vysvětlení spadá mnohem víc do sociologie a psychologie. “33 Pro jeho účely je tento závěr platný. Předkládaný text si ale za cíl klade posouzení kryptoměn a kryptoměnových peněženek z pohledu občanského práva - klasifikovat je jako věc ve smyslu obč. zák. a zhodnotit, jaké právní vztahy vznikají mezi jednotlivými uživateli konkrétního blockchainu, resp. konkrétní kryptoměny. Zváženy budou také důsledky těchto závěrů ve vztahu

2 POLČÁK, Radim, KASL, František, LOUTOCKÝ, Pavel. MÍŠEK, Jakub, STUPKA, Václav. Virtualizace právních vztahů a nové regulatorní metody v pozitivním právu, Právník, roč. 2019, č. 1, s. 86; nebo POLČÁK, Radim. Právo informačních technologií. Praha: Wolters Kluwer ČR, 2018, s. 8.

3 KOUBSKÝ, Petr. Před deseti lety vymyslel Satoshi Nakamoto peníze, kterými si budou navzájem platit roboti. Deník $N$, [online]. Dostupné z: https://denikn.cz/11417/preddeseti-lety-vymyslel-satoshi-nakamoto-penize-kterymi-si-budou-navzajem-platit-roboti [cit. 2019-02-17]. 
k absolutním majetkovým právům, zejména právu dědickému a zástavnímu.

\section{STRUČNÝ POPIS PROTOKOLU BLOCKCHAIN A DEFINICE KRYPTOMĚNY}

Pro zasazení do širšího kontextu a jako východisko pro další text je vhodné začít stručným popisem protokolu blockchain a definovat pojem „kryptoměny“.

Je možné souhlasit s konstatováním, že „[i] nejjednodušši počítač je natolik složitou strukturou, že jeho skutečné fungování není do důsledku schopen pochopit ani profesionál. “4 Internet využívalo podle odhadu v roce 2017 jen v Evropě přes 501 milionů uživatelů ${ }^{5}$ Těžko ale odhadnout, jaké procento těchto uživateli̊ by dokázalo uspokojivým způsobem popsat a vysvětlit, jak vlastně internet jako takový funguje. Totéž platí zde. Pro uživatele konkrétní kryptoměny, ani pro její právní klasifikaci není nutné chápat všechny aspekty jejího technologického pozadí. Cílem zde tedy není detailní vysvětlení technické stránky fungování kryptoměn, je nicméně nezbytné do něj přinést alespoň základní vhled.

První kryptoměna - bitcoin ${ }^{6}$ - vznikla před 10 lety a teoreticky jí dala základ práce Bitcoin: A Peer-to-Peer Electronic Cash System ${ }^{7}$ publikovaná $\mathrm{v}$ roce 2009. V ní je představena peer-to-peer sít Bitcoin, ve které dochází k online transakcím jednotek kryptoměny bitcoin bez využití jakékoliv finanční instituce jako důvěryhodné třetí strany zprostředkovávající tuto transakci.

4 POLČÁK, Radim, KASL, František, LOUTOCKÝ, Pavel. MÍŠEK, Jakub, STUPKA, Václav. Virtualizace právních vztahů a nové regulatorní metody v pozitivním právu. Právník, AV ČR, Ústav státu a práva, 2019, roč. 2019, č. 1, s. 86.

5 International Telecommunication Union. Percentage of Individuals using the Internet. [online]. Dostupné z: https://www.itu.int/en/ITU-D/Statistics/Documents/statistics/2018 /Individuals_Internet_2000-2017_Dec2018.xls, [cit. 2019-03-20].

6 Text dále užívá „bitcoin“ pro kryptoměnu a „Bitcoin“ jako název konkrétního protokolu blockchain, prostřednictvím kterého dochází $\mathrm{k}$ převodům kryptoměny bitcoin.

7 NAKAMOTO, Satoshi. Bitcoin: A Peer-to-Peer Electronic Cash System, [online] Dostupné z: https://bitcoin.org/bitcoin.pdf [cit 2019-03-20]. 
Kromě zprostředkování transakce sít také řeší problém možného dvojího použití prostředků (double spending). ${ }^{8} \mathrm{~K}$ vysvětlení je možné uvést příklad finanční hotovosti. Pokud použiji při platbě obchodníkovi hotovost, nemůžu tutéž stokorunu použít vícekrát. $\mathrm{V}$ případě bezhotovostního převodu mezi dvěma bankovními účty brání dvojímu použití prostředků samotné banky jako třetí osoby zprostředkovávající bezhotovostní převod. U bitcoinu však třetí osoba jako zprostředkovatel transakce chybí, a proto musí fungovat systém bránící užití týchž prostř̌edků vícekrát. Výše zmíněná práce přišla s originálním řešením, kdy je elektronická mince definována jako řetěz elektronických podpisů. Transakce mezi dvěma stranami pak probíhá prostřednictvím protokolu nazývaného blockchain. ${ }^{9}$

Blockchain je typ technologie, resp. protokolu distribuovaných záznamů (anglicky DLT - Distributed Ledger Technology). Jde o distribuovanou decentralizovanou - databázi (někdy popisovanou jako decentralizovaná účetní kniha) používanou mezi všemi uživateli konkrétní sítě a kryptoměny - v tomto prŕípadě Bitcoinu. Jakákoliv transakce provedená v této síti je ověřována ostatními uživateli (nazývanými jako těžaři) z toho hlediska, zda převáděné jednotky kryptoměny daný uživatel skutečně vlastní, a zda nejde o prostředky, které uživatel použil vícekrát. Těžaři ověřují transakce, přičemž každou jimi ověřenou transakci přidají do tzv. bloku s dalšími transakcemi a následně mezi sebou soutěží o to, který z těžařù vytěží nový blok, tedy bude moci vytvořit nový blok s oveřenými transakcemi, jenž je odeslán ostatním uživatelům. To probíhá zjednodušeně řečeno tak, že výpočetní zařízení jednotlivých těžařů tipuji ${ }^{10}$ nižší nebo stejnou hodnotu velice složitého čísla, které je přidělené novému bloku a matematickou funkcí převedena do tzv. hashe ${ }^{11}$. Uhodnout daný hash je natolik složité, že

8 STROUKAL, Dominik. SKALICKÝ, Jan. Bitcoin a jiné kryptopenize budoucnosti. Praha: Grada. 2018. s. 27.

9 NAKAMOTO, Satoshi. Bitcoin: A Peer-to-Peer Electronic Cash System, [online] Dostupné z: https://bitcoin.org/bitcoin.pdf [cit 2019-03-20]. s. 2.

10 Srov. KASL, František. Blockchain, společenská smlouva digitálního věku? Revue pro právo a technologie. 2018, č. 17, s. 13.

11 Složité vstupní číslo je zde matematickou funkcí převedeno do menšího 64místného „čísla“ - jeho otisku (hashe) -, který je prostřednictvím výpočetní techniky „hádán“ těžaři. Příklad hashe je následující: $000000000000000000176 d 22$ e825c9a1941660e4b8f9d1d6918b791 
za použití specializované výpočetní techniky tento proces trvá něco kolem 10 minut. Těžař, který příslušný hash uhodne, vytvoří blok s jím ověřenými transakcemi, který je distribuován mezi ostatní uživatele sítě. ${ }^{12}$

Těžba nového bloku je natolik nákladná, složitá a nejistá, že těžaři musí dostat nějakou odměnu. Za nově vytvořený (vytěžený) blok dostane těžař určitý počet nově do sítě emitovaných bitcoinů. $V$ době přípravy článku jde o 12,5 bitcoinu. ${ }^{13}$ Nad rámec této odměny těžaři ještě náleží poplatky spojené s transakcemi zapsanými do „vytěženého“ bloku.

Každý nový blok obsahuje kromě záznamu o stavu sítě také své vlastní identifikační údaje (hash) a identifikační údaje předchozího bloku. Nelze tak vytvořit fiktivní blok, který by nepasoval do celého „řetězu“ ostatních (kvůli vzájemně propojenému řetězu bloků je protokol nazývaný jako blockchain). Kromě bezpečnosti proti „falšování“ je databáze zapsaná v blockchainu také odolná proti svému zničení. Neexistuje totiž žádná centrální autorita, která by ji spravovala, ale je distribuována mezi všechny uživatele. $^{14}$ Blok je nejdůležitější součást protokolu blockchain, protože zahrnutím transakce do bloku je transakce potvrzena. Blok v prostředí bitcoinu také obsahuje transakci, jejímž prostřednictvím vznikají nové bitcoiny a dostávají se tak do oběhu.

Vzhledem k uvedenému charakteru protokolu blockchain a jejich samotnému názvu, jsou kryptoměny přítomné pouze ve své nehmotné podobě. Vlastněné jednotky kryptoměny pak má uživatel uloženy v některém druhu virtuální peněženky, vlastnictví k nim prokazuje prostřednictvím kryptografie a převod jednotek mezi dvěma adresami

\section{f32416618.}

12 Proof of Work. Investopedia. [online]. Dostupné z: https://www.investopedia.com/terms p/proof-work.asp, [cit. 2020-01-20].

13 K 27.3.2020 má 12,5 bitcoinu hodnotu přes 2,8 milionu českých korun (dle kryptoměnové směnárny CoinBase https://www.coinbase.com/).

14 Srov. např. KASL, František. Blockchain, společenská smlouva digitálního věku? Revue pro právo a technologie. 2018, č. 17, s. 11. Zde autor dochází k závěru, že „[z] hlediska legitimity je atraktivní, že mechanismus nemá zjevnou centrální definiční autoritu, ale stanoví oprávněnost vnitřních pravidel skrze aktivitu širokého spektra uživatelů, kteři se spolupodílejí na jeho vytváření a jeho užíváním schvalují jeho obsah." 
peněženky je možný pouze prostřednictvím blockchainu. ${ }^{15}$ To však neplatí pro hardwarové peněženky, které si lze představit zjednodušeně např́klad jako flashdisk suloženými jednotkami kryptoměn, který je možné jednoduše fyzicky někomu předat, a pro situace, kdy má uživatel svůj privátní a veřejný klíč $k$ virtuální peněžence pouze fyzicky vytištěný $\mathrm{v}$ listinné podobě a obojí může opět pouze fyzicky předat dalšímu uživateli.

Adresu lze definovat jako jednoznačnou identifikaci odesílatele nebo př́ijemce platby. Vlastnictví takové adresy je poté prokazováno prostřednictvím transakce podepsané tzv. soukromým klíčem.

Je třeba uvést, že tento popis neplatí obecně pro všechny kryptoměny. Způsob „těžby“ nových bitcoinů a ověřování transakcí těžaři je v této a obdobných sítích nazývaný jako proof of work. Některé jiné kryptoměny užívají proof of stake, kdy je právo vytvořit nový blok připisováno mimo jiné dle množství vlastněných jednotek kryptoměny. ${ }^{16}$ Existují však i další typy důkazů, resp. způsobů dosažení konsenzu o stavu dané kryptoměny např. delegated proof of stake, proof of importance, proof of authority ${ }^{17}$ či proof of activity ${ }^{18}$.

Pro ilustraci lze uvést další rozdíly mezi různými kryptoměnami. $\mathrm{V}$ př́padě bitcoinu je $\mathrm{s}$ vytěžením bloku spojena odměna $\mathrm{v}$ podobě do sítě nově přidaných bitcoinů. U některých kryptoměn jsou nové jednotky distribuovány mezi uživatele jiným způsobem nebo naprosto náhodně. Množství bitcoinů, které budou celkem vydány je finální. ${ }^{19} \mathrm{~V}$ jiných kryptoměnách je toto množství naopak neomezené či je naopak v síti od počátku v oběhu již finální množství jednotek a nové jednotky se netěží. ${ }^{20}$

\footnotetext{
15 LÁNSKÝ, Jan. Kryptoměny. 1. vydání. Praha: C. H. Beck, 2018. s. 3.

16 Proof of Stake. Investopedia. [online]. Dostupné z: https://www.investopedia.com/terms/ p/proof-stake-pos.asp, [cit. 2020-01-20].

17 LÁNSKÝ, Jan. Kryptoměny. 1. vydání. Praha: C. H. Beck, 2018. s. 20 a násl.

18 BENTOV, Iddo et al. Proof of activity: extending bitcoin's proof of work via proof of stake. In Proceedings of the ACM SIGMETRICS 2014 Workshop on Economics of Networked Systems, NetEcon 2014: [online]. Dostupné z: https://eprint.iacr.org/2014/452.pdf [cit. 2020-01$20]$.

19 STROUKAL, Dominik. SKALICKÝ, Jan. Bitcoin a jiné kryptopeníze budoucnosti. Praha: Grada. 2018. s. 32.

${ }^{20}$ LÁNSKÝ, Jan. Kryptoměny. 1. vydání. Praha: C. H. Beck, 2018. s. 32 a násl.
} 
Na základě výše uvedeného bude pro účely tohoto textu kryptoměna definována jako druh virtuální měny ${ }^{21}$ :

1. jejíž vlastnictví se prokazuje pouze prostřednictvím kryptografie,

2. vlastnictví je evidováno prostřednictvím decentralizované a distribuované databáze blockchain, a

3. její transakce mezi uživateli je možné provádět pouze elektronicky prostřednictvím konkrétního protokolu blockchain. ${ }^{22}$

\section{ZÁKONNÁ ÚPRAVA KRYPTOMĚN}

Jediným zákonným ustanovením, které se výslovně věnuje virtuálním měnám, jejichž zástupcem jsou i kryptoměny, je $\S 2$ odst. 1 písm. 1) zákona č. 253/2008 Sb., o některých opatřeních proti legalizaci výnosů z trestné činnosti a financování terorismu. Ten virtuální měnou pro účely tohoto zákona rozumí elektronicky uchovávanou jednotku bez ohledu na to, zda má nebo nemá emitenta, a která není peněžním prostředkem podle zákona o platebním styku ${ }^{23}$, ale je přijímána jako platba za zboží nebo služby i jinou osobou odlišnou od jejího emitenta.

Na evropské úrovni jsou virtuální měny definovány směrnicí Evropského parlamentu a Rady (EU) 2015/849, o předcházení využívání finančního systému k praní peněz nebo financování terorismu ${ }^{24}$, jako digitální reprezentace hodnoty, která není vydána či garantována centrální bankou ani orgánem veřejné moci, není nutně spojena se zákonně stanovenou měnou a nemá právní status měny či peněz, je však fyzickými nebo právnickými osobami přijímána jako prostředek směny a může být elektronicky převáděna, uchovávána a obchodována.

21 Ne všechny virtuální měny jsou spojeny s kryptografií.

22 Pro vyčerpávající definici kryptoměny srov. LÁNSKÝ, Jan. Kryptoměny. 1. vydání. Praha: C. H. Beck, 2018, s. 3.

23 Nyní zákon č. 370/2017 Sb., o platebním styku.

24 Směrnice Evropského parlamentu a rady (EU) 2015/849 ze dne 20. května 2015, o předcházení využívání finančního systému k praní peněz nebo financování terorismu, o změně nařízení Evropského parlamentu a Rady (EU) č. 648/2012 a o zrušení směrnice Evropského parlamentu a Rady 2005/60/ES a směrnice Komise 2006/70/ES 
Pokud kryptoměny nejsou nijak výslovně regulovány, je na místě otázka, zda je jejich užívání vlastně legální. S odkazem na zásadu legální licence, tedy že každý může činit, co není zákonem zakázáno ${ }^{25}$, lze odpovědět, že ano. Je však nutné vzít v úvahu zákaz převodu finančních prostředků nad stanovený limit mimo bezhotovostní platby prostřednictvím bankovního převodu. V této souvislosti Ministerstvo financí vyzývá veškeré povinné osoby, „aby $v$ souvislosti s nákupem/prodejem jakékoli digitální měny, jako je např́klad Bitcoin, byla jako velmi riziková $k$ posouzení a $k$ rozhodnutí o dalších opatřeních podle okolností každá platba nad hodnotu 1.000 EUR a v̌̌dy jako podezřelý obchod postupem podle $\S 18$ AML zákona oznámena transakce nad hodnotu 15.000 EUR. “26

Soukromoprávní předpisy však virtuální měny ani kryptoměny nijak nedefinují. Občanskoprávní teorie se však již kryptoměnám a protokolu blockchain začíná pomalu věnovat, jak vyplývá mimo jiné z přehledu použité literatury uvedeného v závěru tohoto textu.

\section{NABÍDKA A POPTÁVKA PŘI UŽÍVÁNÍ KRYPTOMĚNY}

\subsection{OBECNĚ K NABÍDCE A POPTÁVCE}

Bylo uvedeno, že $\mathrm{v}$ případě převodu jednotek kryptoměny bitcoin mezi jednotlivými uživateli, resp. adresami jejich virtuálních peněženek, je nutné, aby transakci ověřili ostatní uživatelé „těžící“ nové jednotky kryptoměny a konkrétní těžař transakci zařadil do nově vytvářeného bloku transakcí. Původně byly transakce těžaři ověřovány bez poplatku. Postupně však začal narůstat celkový počet transakcí a zároveň lze do nového bloku zařadit jen množství transakcí odpovídající jeho velikosti. Proto je možné ke každé transakci připojit poplatek v libovolné výši, který při jejím zařazením do nového bloku náleží těžaři, jež tento nový blok vytěží. V zásadě pak platí, že připojí-li uživatel k transakci vyšší poplatek, je

${ }^{25}$ Článek 2 odst. 4 ústavního zákona č. 1/1993 Sb., Ústava České republiky.

${ }^{26}$ Metodický pokyn č. 2 Finančního analytického útvaru Ministerstva financí ze dne 16. září 2013, Č.j.: MF-86584/2013/24. 
transakce do nového bloku v rámci protokolu blockchain zapsána dříve, než srovnatelná transakce bez poplatku nebo s nižším poplatkem. ${ }^{27}$

S ohledem na uvedený postup je vhodné posoudit, jaký vztah vzniká mezi uživateli, kteří převádí jednotky kryptoměny, a těžaří, kteří transakci ověřují a zapisují do nového bloku transakcí.

V § 1731 obč. zák. čteme, že z návrhu na uzavření smlouvy, resp. z nabídky musí být zřejmé, že nabízející má úmysl uzavřít určitou smlouvu s osobou, vůči které je nabídka určena. Nabídka je perfektní, pokud z právního jednání směřujícího $\mathrm{k}$ uzavření smlouvy plyne vůle navrhovatele být smlouvou vázán, obsahuje-li alespoň podstatné náležitosti smlouvy a je možné uzavřít ji jednoduchou, bezvýhradní akceptací nabídky. Podstatnými náležitostmi smlouvy jsou ty, které je nutno dohodnout, aby na základě právního jednání byla uzavřena smlouva, resp. ty náležitosti, o nichž některá ze stran prohlásí, že o nich musí být dosaženo dohody. ${ }^{28}$

Základní definice nabídky tedy stanovuje, že nabídka musí jasně vyjadřovat oferentovu vůli uzavřít konkrétní smlouvu s osobou, vůči které je nabídka učiněna. To znamená, že nabídka musí být obecně adresována konkrétní osobě. Na druhou stranu ne vždy je nabídka vůči konkrétní osobě směřována. Pravděpodobně nejčastější neadresná nabídka je nabídka dodat zboží nebo poskytnout určitou službu učiněná ve spojení s podnikatelskou činností oferenta prostřednictví reklamy, katalogu nebo vystavením v obchodě. Nikoliv pouze podnikatelé ale mohou činit neadresné nabídky. Ustanovení § 1780 odst. 1 obč. zák. definuje veřejnou nabídku jako projev vůle navrhovatele, kterým se obrací na neurčité osoby s návrhem na uzavření smlouvy. Zároveň platí, že podnět $\mathrm{k}$ uzavření smlouvy, $\mathrm{z}$ něhož neplyne úmysl uzavř́t určitou smlouvu nebo který nemá náležitosti podle § 1732 odst. 1 obč. zák., se považuje za výzvu k podávání nabídek.

${ }^{27}$ Srov. např. STROUKAL, Dominik. SKALICKÝ, Jan. Bitcoin a jiné kryptopeníze budoucnosti. Praha: Grada. 2018. s. 70.

${ }^{28}$ PELIKÁNOVÁ. Irena. PELIKÁN, Robert. in ŠVESTKA, Jiří. DVOŘÁK, Jan. FIALA, Josef a kol. Občanský zákoník. Komentář. [Systém ASPI]. Praha: Wolters Kluwer ČR. Komentář $\mathrm{k} \S 1732$. [cit. 2019-11-20]. 


\subsection{PRÁVNÍ VZTAH PŘI PŘEVÁDĚNÍ KRYPTOMĚNY}

Budeme-li aplikovat výše uvedené $\mathrm{v}$ předchozí části na fungování kryptoměn a převodu jednotek kryptoměny mezi adresami virtuálních peněženek uživatelů, dojdeme $\mathrm{k}$ závěru, že mezi uživatelem převádějícím jednotky a těžařem, který tuto transakci zahrne do nového bloku zařazovanému do blockchainu vzniká relativní závazkový vztah.

Tento závěr lze ilustrovat na př́kladu kryptoměny bitcoin, nicméně bude přiměřeně platný i pro jiné kryptoměny. Uživatel se rozhodne, že převede stanovený počet jednotek a připojí $\mathrm{k}$ této transakci poplatek $\mathrm{v}$ jím stanovené výši. Tím je konstituována veřejná nabídka ve smyslu § 1780 odst. 1 obč. zák. Uživatel zde nabízí, že po uznání transakce za platnou a jejím zapsání do blockchainu bude těžaři zaplacen připojený poplatek. Tato oferta nemůže být adresná a je směřována předem neurčeným osobám proto, že těžař nemůže garantovat to, že $\mathrm{z}$ jeho strany bude nový blok vytěžen, tedy že získá právo zapsat nový blok do blockchainu. Toto právo totiž vzniká $\mathrm{v}$ zásadě na základě náhody - uhodnutím předem stanoveného hash nového bloku.

Zapsáním transakce do nového bloku je oferta těžařem akceptována a je mu vyplacen připojený poplatek. Zde je nutné uvést, že vzhledem k samotnému nastavení sítě (protokolu blockchain) není možné, aby v této situaci vznikla povinnost, kterou by pak bylo možné, resp. nutné vymáhat. Není totiž možné, aby těžař inkasoval poplatek bez zapsaní transakce do blockchainu, a zároveň není možné transakci zapsat a neobdržet stanovený poplatek. V př́padě tohoto postupu jde o jednoduchou formu smart kontraktu, který se sám vykoná, tedy automatický vyplatí připojený poplatek.

Také je třeba konstatovat, že žádnému z těžařů $\mathrm{v}$ žádném okamžiku nevyplývá povinnost transakci ověřit a zapsat. Záleží na tom, zda sít dojde ke konsenzu, že transakce je platná, tedy že převodce převáděnými jednotkami skutečně disponuje či je nepřevádí podruhé (tzv. doublespending), a že těžař přijme nabídku za stanovený poplatek transakci zapsat. Ze strany těžaře $\mathrm{v}$ podstatě dojde $\mathrm{k}$ posouzení, zda se mu vyplatí do nového bloku transakci zapsat za tento poplatek, nebo zapíše transakci 
jinou, zabírající více místa, k níž je však připojen vyšší poplatek. Pokud se konkrétní těžař při vytváření nového bloku rozhodne transakci do nového bloku nezapsat, neznamená to, že by převodce musel transakci zadávat znovu. Jiný těžař může při vytěžení dalšího bloku transakci zapsat do něj.

\section{KRYPTOMĚNA JAKO VĚC DLE OBČANSKÉHO ZÁKONÍKU}

\subsection{OBECNÝ VÝKLAD O VĚCECH DLE OBČ. ZÁK.}

Věcí v právním smyslu rozumí obč. zák. svým § 489 vše, co je rozdílné od osoby a slouží k potřebě lidí.

Aby obč. zák. podle $\S 489$ považoval nějaký předmět za věc, musí splňovat kumulativně dva znaky:

1. být rozdílný od osoby, a

2. sloužit $\mathrm{k}$ potřebě lidí.

Vše, co tedy v objektivní realitě není osobou, a zároveň člověku slouží $\mathrm{k}$ potřebě, je věcí v právním smyslu. Potřebnost je dána užitečností věci pro člověka, kterou se rozumí užitek předmětu pro vlastníka a objektivní způsobilost přinášet vlastníkovi především hospodářský, ale i estetický či jiný užitek.

Právní teorie připojuje ještě jeden znak, a to že věc může být předmětem subjektivních majetkových práv, zejména práva vlastnického. ${ }^{29}$ Tento znak je nepřímo součástí § 496 odst. 1 obč. zák., který hmotnou věcí rozumí ovladatelnou část vnějšího světa, která má povahu samostatného předmětu. Je-li pro věc typické, že je předmětem vlastnického práva, a nebude-li jakákoliv hmotná součást objektivní reality ovladatelná, těžko bude moci být hmotnou věcí v právním smyslu. U nehmotných věcí sice není možné o faktické fyzické ovladatelnosti mluvit, to ale nebrání tomu, aby byly předmětem vlastnických práv.

${ }^{29}$ DAVID, Ondřej, KINDL, Tomáš. in ŠVESTKA, Jiří. DVOŘÁK, Jan. FIALA, Josef. a kol. Občanský zákoník. Komentár̆. [Systém ASPI]. Wolters Kluwer [cit. 2019-11-20]. Komentář k § 489; nebo DVOŘÁK, Jan. ŠVESTKA, Jiří. ZUKLÍNOVÁ, Michaela. a kol. Občanské právo hmotné. Svazek I. Díl první. Obecná část. 2. Aktualizované a doplněné vydání. Praha: Wolters Kluwer ČR, 2016, s. 377. 
Vezmeme-li v úvahu všechny tři podmínky pro klasifikaci předmětu jako věci v občanskoprávním pojetí, dojdeme k závěru, že jim kryptoměny vyhovují:

1. Odlišné od právnických a fyzických osob jsou.

2. Slouží k potřebě lidí - mohou být za určitých podmínek prostředkem směny nebo představovat investici. Jejich uživatelé je mohou v rámci blockchainu směnit za jiné věci či práva, mohou na ně nahlížet jako na uchovatele hodnoty či je jako investici nakoupit za měnu s nuceným oběhem s očekáváním nárůstu jejich hodnoty.

$S$ ohledem na decentralizaci kryptoměn a jejich nezávislosti na státu v nich jiní uživatelé mohou hledat finanční svobodu. Často bývají kryptoměny $\mathrm{v}$ této souvislosti skloňovány $\mathrm{s}$ jejich tvrzenou anonymitou. Kryptoměny se $\mathrm{v}$ míře anonymity liší, nicméně $\mathrm{v}$ případě bitcoinu lze mluvit spíše o pseudonymitě. ${ }^{30}$

3. Kryptoměny jsou způsobilé být předmětem subjektivních majetkových práv. Lze je držet a je možné s nimi nakládat. S ohledem na to, že jsou kryptoměny obchodovány na různých burzách, a lze je obchodovat prostřednictvím kryptoměnových „směnáren“, je možné stanovit jejich hodnotu v penězích (§ 492 obč. zák.).

S ohledem na výše uvedené tedy autor konstatuje, že jednotky kryptoměny odpovídají legální definici věci v občanském právu. Tento závěr podporuje i teleologický výklad § 489, kdy široké definici věci v tomto ustanovení vyhovuje rozsáhlá paleta hmotných i nehmotných předmětů. Obč. zák. věc vymezuje záměrně takto široce, aby toto pojetí oproti předchozí úpravě více vyhovovalo čl. 11 odst. 1 Listiny základních práv a svobod ${ }^{31}$ i pojetí mezinárodních smluv a nadnárodních úprav. Důvodová zpráva $\mathrm{k}$ obč. zák. výslovně zmiňuje, že široké vymezení věci pojmově zahrnuje i „předměty spadající do kategorií průmyslového a jiného

\footnotetext{
30 K anonymitě kryptoměn blíže viz LÁNSKÝ, Jan. Kryptoměny. 1. vydání. Praha: C. H. Beck, 2018, s. 57.

31 „Každý má právo vlastnit majetek. Vlastnické právo všech vlastníků má stejný zákonný obsah a ochranu. Dědění se zaručuje."
} 
duševního vlastnictví, zaknihovaných cenných papírů, investičních nástrojů typu opcí, swapů, futures nebo forwardů atd.). ${ }^{\text {(32 }}$ Je-li věc vymezena takto široce, je možné pod definici věci podřadit i jednotky kryptoměny.

Kryptoměny, na rozdíl od měn s nuceným oběhem, nemají svou hotovostní alternativu. ${ }^{33}$ Výše bylo uvedeno, že vlastnictví jednotek kryptoměny se prokazuje výhradně prostřednictvím kryptografie, jejich vlastnictví je evidováno v elektronicky vedené databázi a disponovat s nimi lze pouze elektronicky prostřednictvím protokolu blockchain. Lze je tedy klasifikovat jako nehmotnou věc.

Vzhledem $\mathrm{k}$ tomu, že $\mathrm{k}$ vlastnictví jednotky kryptoměny se neváže žádná povinnost vlastníka ani jiné osoby něco dát, konat, strpět nebo se něčeho zdržet, nebude možné klasifikovat virtuální měnu jako právo. Ustanovení § 1011 obč. zák. konstatuje, že vše, co někomu patří, všechny jeho věci hmotné i nehmotné, je jeho vlastnictvím. Z pohledu občanského práva a uživatele kryptoměny bude tedy vlastně irelevantní, zda bude kryptoměna považována za právo, anebo za jinou věc bez hmotné podstaty, když oba tyto závěry znamenají, že je věcí.

Sporu nebude o tom, že kryptoměny jsou věcí movitou. ${ }^{34}$ Jednoduché to ale není s rozlišením, zda budou věcí zastupitelnou či nezastupitelnou. Zastupitelná je taková věc, která může být nahrazena jinou věcí téhož druhu a množství. Ostatní věci jsou nezastupitelné. Typickým př́íkladem zastupitelné věci jsou peníze. Ač mezi měnami s nuceným oběhem a kryptoměnami nalezneme mnoho odlišností, není podle autora důvod, proč by zákonné peníze měly být považovány za zastupitelnou věc, a jednotky kryptoměny za věc nezastupitelnou.

Peníze mohou sice $\mathrm{v}$ některých případech plnit sběratelskou funkci nebo být jinak individuálně určeny např́klad u bankovek určených čísly. I na jednotky kryptoměny lze nahlížet jako na jedinečný datový záznam, jelikož jejich vlastnictví je prokazováno prostřednictvím asymetrické kryptografie.

\footnotetext{
Srov. důvodová zpráva k obč. zák, § 498.

33 I přes to, že například název kryptoměny „Bitcoin Cash“ by sváděl k opačnému závěru.

34 Pravda je ale taková, že najdou-li se lidé, kteří budou tvrdit, že Země je placatá, mohou se objevit i lidé tvrdící, že kryptoměna je věc nemovitá.
} 
Touto optikou by pak bylo možné jednotky individualizovat a považovat je za věc nezastupitelnou. Na druhou stranu je avšak otázka, zda toto individuální určení má pro vlastníka nějaký význam, ale vyloučit se to zřejmě nedá. Ale stejně jako běžnému uživateli fiat měny pravděpodobně nebude záležet na tom, jestli bude mít $\mathrm{v}$ peněžence konkrétní bankovku určenou sérií a pořadovým číslem nebo jinou bankovku totožné hodnoty z jiné série, nebude zřejmě ani záležet uživateli kryptoměny, jestli k jeho adrese náleží jednotky, které se dostaly do oběhu v úterý ve 12:15 nebo ve středu ve 14:00.

\subsection{CENNÉ PAPÍRY}

Obč. zák. považuje za věc také cenný papír ${ }^{35}$ jako listinu, se kterou je právo spojeno takovým způsobem, že je po vydání cenného papíru nelze bez této listiny uplatnit ani převést, a zaknihovaný cenný papír, $v$ jehož případě je cenný papír nahrazen zápisem do př́slušné evidence a nelze jej převést jinak než změnou zápisu v této evidenci. ${ }^{36}$ Pro kryptoměny jako takové je jejich klasifikace jako cenného papíru, resp. zaknihovaného cenného papíru vyloučena. K tomuto závěru dochází i Česká národní banka, která konstatovala, že bitcoin nevykazuje znaky investičního nástroje ve smyslu § 3 zákona č. 256/2004 Sb., o podnikání na kapitálovém trhu, protože nemá povahu cenného papíru, zaknihovaného cenného papíru ani derivátu. ${ }^{37}$

Teoreticky by bylo možné uvažovat jako o cenných papírech u tzv. tokenů používaných prostřednictvím protokolu blockchain. Tokeny mohou mít platební formu sloužící ke směně za nějaké zboží či službu, pak se svým charakterem blíží kryptoměnám. Většinou ale budou používány jako přístup k nějaké službě založené na blockchainu nebo k účasti na projektu

35 PAULY, Jan. Teoretické a legislativní základy cenných papírů. [Systém ASPI]. Wolters Kluwer. 2016. Kapitola 1. [cit. 2020-03-14]. nebo MAREK, Radan. in MAREK, Radan, JEŽEK, Václav. Cenné papíry v novém občanském zákoníku. 1. vydání. Praha: Nakladatelství C. H. Beck, 2013, s. 1.

${ }^{36} \S 514$ a $\S 525$ odst. 1 obč. zák.

37 Obchodování s bitcoiny / Je k obchodování s bitcoiny nebo k jejich směně potřebné povolení ČNB? [online]. Dostupné z: https://www.cnb.cz/miranda2/export/sites/www. cnb.cz/cs/faq/stanoviska_a_odpovedi/pdf/obchodovani_s_bitcoiny.pdf [cit. 2019-03-17]. 
financovaném právě emisí tokenů. $\mathrm{V}$ této souvislosti jsou tokeny někdy přirovnávány $\mathrm{k}$ dluhopisům nebo akciím. Akciím jsou zřejmě nejpodobnější tzv. equity tokeny, které reprezentují podíl na právnické osobě, a vlastník se jimi podílí na jejím řízení.

Mimo jiné vzhledem k legální definici cenného papíru jako listiny a nutnosti zapsat zaknihovaný cenný papír do evidence, které blockchain nebude vyhovovat (srov. § 91 zákona č. 256/2004 Sb., o podnikání na kapitálovém trhu), nebude ani tokeny možné podřadit pod cenné papíry ani zaknihované cenné papíry. ${ }^{38}$

Na druhou stranu o některých formách tokenů by mohlo být uvažováno jako o převoditelných cenných papírech, jakožto pojmu práva Evropské unie. $^{39}$

\subsection{ADRESA A PENĚŽENKA JAKO VĚC}

Při širokém vymezení věci občanským zákoníkem bude podle autora možné za nehmotnou věc považovat i adresu v rámci kryptoměnové sítě, ke které jednotky kryptoměny náleží. Nebudou zřejmě pochybnosti o charakteristice hardwarové peněženky, na které jsou nahrány jednotky (resp. kryptoměnová adresa), jako hmotné věci. Tu však lze vnímat pouze jako hmotný substrát, na kterém je uložen soukromý a veřejný klíč $\mathrm{k}$ př́slušné adrese. Sporné může být, zda za věc považovat i adresu samotnou. $\mathrm{S}$ ohledem na širokou definici věci v občanském zákoníku by se autor přikláněl $\mathrm{k}$ tomu, že ano, a to $\mathrm{s}$ přihlédnutím ke všem dříve uvedeným závěrům $s$ tím, že $v$ případě adresy půjde o nezastupitelnou věc $\mathrm{s}$ ohledem na její jedinečnost $\mathrm{v}$ rámci sítě. Každá adresa je totiž identifikována svým unikátním veřejným klíčem, ke kterému patří

${ }^{38} \mathrm{~V}$ podrobnostech lze odkázat na text, ve kterém jsou tokeny také klasifikovány jako věci, kdy podle autorů ,je token nehmotnou movitou věcí odpovídajicí právu jejího vlastníka na př́stup $k$ určité službě nebo produktu, které emitent tokenu nabizí, nebo právu podílet se určitým způsobem na projektu, který emitent tokenu financuje prostředky získanými od investorů." DĚDIČ, Jan. ŠOVAR, Jan. MIKULA, Ondřej. Proč podle českého soukromého práva nelze uvažovat o (ICO) tokenech jako o cenných papírech. Právní rozhledy. 2018, č. 15-16, s. 554-556.

${ }^{39} \mathrm{~V}$ podrobnostech srov. HOBZA, Martin. ICO a tokeny optikou práva kapitálového trhu: mohou být tokeny investičními cennými papíry? Bulletin advokacie. 2019, č. 3, s. 41-46. 
neodmyslitelně klíč soukromý. Tedy jednu adresu nebude možné nahradit jednoduše jinou, a to ani $\mathrm{v}$ případě, že by na ní bylo nahráno totožné množství jednotek.

Tento úsudek lze podpořit tím, že i bankovní účet je možné považovat po 1. 1. 2014 za věc. Bankovní účet sice jako takový není zákonem vymezen a občanský zákoník pouze definuje smlouvu o účtu tak, že se jí ten, kdo vede účet, zavazuje zřídit od určité doby v určité měně účet pro jeho majitele, umožnit vložení hotovosti na účet nebo výběr hotovosti z účtu nebo provádět převody peněžních prostředků z účtu či na účet. Je tedy možné ho označit za evidenci pohledávky majitele za osobou, která účet vede, a vice versa dluhu osoby vedoucí účet vůči jejímu majiteli. Po účinnosti občanského zákoníku je možné bankovní účet vzhledem k vymezení věci v $§ 489$ obč. zák. považovat za nehmotnou movitou věc. ${ }^{40}$

\section{KRITICKÝ POHLED NA PŘEDCHOZÍ ZÁVĚRY}

Je možné připustit, že debata o podrobné charakteristice jednotek kryptoměn jako věci je do jisté míry akademická a pro jejich běžného uživatele bezpředmětná. Zde má autor na mysli například jejich klasifikaci jako nehmotnou věc či právo. Je-li právo, jehož povaha to připouští, občanským zákoníkem zařazeno mezi nehmotné věci, vlastníku jednotek kryptoměny zřejmě nebude záležet na tom, zda bude vlastníkem jiné věci bez hmotné podstaty, anebo práva, jehož povaha to připouští - a tedy nehmotné věci.

Tuto debatu lze také do jisté míry prrirovnat k obdobné, která byla vedena ohledně zařazení cenných papírů mezi věci či jiné majetkové hodnoty před účinností obč. zák. Doktrína dříve vesměs nepovažovala cenný papír za věc, ale za statek naplňující znaky jiné majetkové hodnoty. A to přes to, anebo právě proto, že tehdy platný zákon č. 591/1992 Sb., o cenných papírech, hned ve svém prvním paragrafu určoval, že na cenné papíry se vztahují ustanovení o věcech movitých. Cenný papír tedy nebyl věcí v právním smyslu, ale soudy například dovozovaly, že může být

40 ELEK, Štefan; LIŠKA, Petr; MAREK, Karel. Bankovní obchody. [Systém ASPI]. Kapitola III, $\S 1$. Wolters Kluwer [cit. 2020-03-14]. 
postižen výkonem rozhodnutí nebo že je možné ho vydržet. ${ }^{41}$ Pro držitele cenného papíru, jenž se věcí nezabýval na akademické úrovni, tak byl výsledek relativně bezvýznamný - na cenný papír se vztahovala ustanovení o movitých věcech, bylo možné ho vydržet a mohl být předmětem výkonu rozhodnutí. Záleží pak jeho vlastníkovi na tom, jestli je věcí v právním smyslu nebo ne? Zřejmě nikoliv.

Tématu textu je však ještě blíže debata o tom, zda je zaknihovaný cenný papír spíše „zaknihované právo“, tj. právo, jehož povaha to připouští, a tedy nehmotnou věcí, anebo rovnou jinou věcí bez hmotné podstaty. ${ }^{42}$ Zde také vlastníkovi zaknihovaného cenného papíru půjde primárně o to, zda se bude moci při uplatnění práv prokázat výpisem z př́slušné evidence zaknihovaného papíru, a zda bude moci se zaknihovaným papírem v rámci této evidenci relativně volně disponovat, a to bez ohledu na výsledek této diskuze.

Podobně lze prripomenout spory ohledně charakteristiky doménových jmen a jejich ochrany. Ty by však po účinnosti obč. zák. měly být ukončeny, a to vzhledem $\mathrm{k}$ širokému pojetí definičního ustanovení o věcech. ${ }^{43}$

Považujeme-li kryptoměnu za věc, znamená to, že její jednotky budou způsobilé být předmětem absolutních i relativních subjektivních práv. Budou předmětem vlastnického práva jako absolutního práva a budou způsobilé býti předmětem závazku jako práva relativního. Je ale nutné připustit, že tento závěr má své limity vzhledem k povaze kryptoměn a možnostem $s$ jejich jednotkami reálně disponovat.

Občanský zákoník pojímá vlastnictví jako vlastníkovo právo vlastnictvím v mezích právního řádu libovolně nakládat a jiné osoby $\mathrm{z}$ toho

\footnotetext{
${ }^{41}$ Např. rozhodnutí Nejvyššího soudu 21 Cdo 2587/99 či 29 Odo 1216/2005.

${ }^{42}$ Srov. např. SZOSTOK, David. Cenný papír a zaknihovaný cenný papír jako věc v právním smyslu, Soukromé právo, 2016, č. 11. či VÍTEK, Jindřich. Právní úprava cenných papírů v občanském zákoníku. Obchodní právo, 2012, č. 12.

43 MACGREGOR PELIKÁNOVÁ, Radka. (Ne)jasné pojetí doménových jmen a jejich režimu v novém občanském zákoníku. Rekodifikace \& Praxe, 2015, č. 3(1).
} 
vyloučit. ${ }^{44}$ Jako jednotlivá oprávnění vlastníka bývají uváděna dílčí práva: věc užívat, požívat, nakládat s ní, zničit ji či ji opustit. ${ }^{45}$

Tato oprávnění jsou však v prostředí protokolu blockchain limitována jeho pravidly a asymetrickou kryptografií. Jakákoliv dispozice s jednotkami kryptoměny je závislá na pravidlech konkrétní sítě. Zároveň je třeba vzít v úvahu, že formálně mohu být vlastníkem jednotek kryptoměny, resp. adresy, na které jsou v určitém okamžiku zapsané, nicméně bez znalosti soukromého kryptografického klíče k této adrese s nimi nebudu schopný provést jakoukoliv dispozici. Na této skutečnosti nezmění nic ani teoretické rozhodnutí soudu, které bude vlastníkovi přikazovat vydat jednotky kryptoměny zapsané na konkrétní adrese specifikované veřejným klíčem, když bez soukromého klíče a součinnosti těžařů, jak bylo uvedeno výše, nebude možné převod uskutečnit.

Těžko se také může vlastník rozhodnout jednotky kryptoměny zničit. Dalo by se hovořit například o spálení jediného výtisku listiny se zapsaným soukromým klíčem či o úderech kladivem do hardwarové peněženky, na které budou zapsány. K faktickému zničení těchto jednotek však nedojde v síti budou existovat dále, jen s nimi nebude žádný z uživatelů (včetně jejich vlastníka) schopen jakkoliv disponovat. Jediné ze zmíněných oprávnění vlastníka, které bude proveditelné vždy, bude tedy právo věc opustit. $^{46}$

Charakteristika jednotek kryptoměny jako věci také znamená, že je možné je užít v rámci různých institutů občanského práva. I toto užití má své hranice, které je možné ilustrovat na příkladu klasického institutu občanského práva - na zástavním právu - a také na právu dědickém.

\footnotetext{
${ }^{44} \S 1012$ obč. zák.

${ }^{45}$ Srov. např. SPÁČIL, Jiří in SPÁČIL, Jiří a kol. Věcná práva. Věcná práva, katastr nemovitostí a správa cizího majetku. Praha C. H. Beck, 2018, s. 53.

${ }^{46} \mathrm{~V}$ této věci lze odkázat na článek POLČÁK, Radim. Informace a data v právu. Revue pro právo a technologie, MUNI, roč. 2016, č. 13, s. 68-91. Zde je prezentován závěr, že data mohou být předmětem absolutních práv pouze za předpokladu, že "jsou data tak pevně spojena se svým nosičem nebo službou zajištujicím jejich dostupnost, že nelze docílit jejich samostatného užití. Druhý výjimečný př́pad nabízí silné šifrovací nástroje, jejichž aplikace umožňuje prakticky svázat užití dat s užitím dešifrovacího postupu."
} 
Zástavou může být každá věc, s níž lze obchodovat, a zástavní právo lze zřídit i $\mathrm{k}$ věci, $\mathrm{k}$ níž zástavnímu dlužníku vznikne vlastnické právo teprve v budoucnu. ${ }^{47}$ Vzhledem $\mathrm{k}$ dříve uvedeným závěrům lze konstatovat, že jednotky kryptoměny budou způsobilou zástavou - jsou věcí a lze s nimi obchodovat.

Alternativně bude možné zastavit i samotnou adresu v rámci konkrétní sítě či hardwarovou peněženku. Pro podporu závěru o charakteristice kryptoměnové adresy jako věci bylo použito srovnání s bankovním účtem, který lze za věc považovat také. ${ }^{48}$ Zde je však této analogii třeba vymezit hranice $\mathrm{z}$ toho důvodu, že způsobilou zástavou bude sice pohledávka majitele účtu vưči bance, nikoliv bankovní účet jako takový. ${ }^{49}$

Problém při zastavení adresy jako takové nebude v naplnění zákonného předpokladu vzniku zástavního práva k movité věci (zástavní právo k movité věci ze zákona vzniká odevzdáním věci zástavnímu věřiteli ${ }^{50}$ ) ani v jejím zpeněžení po splatnosti dluhu. Nepůjde však zamezit tomu, aby s jednotkami kdokoliv další disponoval. Předá-li totiž zástavní dlužník zástavnímu věřiteli (anebo třetí osobě ve smyslu § 1318 obč. zák.) soukromý i veřejný klíč k adrese, neznamená to samozřejmě, že je po jejich předání nebude moci $\mathrm{k}$ převodu jednotek použít. Tomu zástavní věřitel prakticky nemůže zabránit, s výjimkou relativního závazku zřízeného mezi zástavním dlužníkem a věřitelem. Stejně to bude platit i pro zastavení hardwarové peněženky, která sice může být jednoduše odevzdána, resp. po splatnosti dluhu zpeněžena. To však opět neznamená, že zástavní dlužník nebo třetí osoba mezitím nemůže s jednotkami disponovat. Adresa např́íklad může být naklonovaná na dvou a více různých hardwarových peněženkách, které převod jednotek umožní.

\footnotetext{
47 § 1310 obč. zák.

48 LIŠKA, Petr. Účet, jednorázový vklad, akreditiv a inkaso v občanském zákoníku. [Systém ASPI]. Wolters Kluwer [cit. 2020-03-14]. Část první, hlava II.

49 K tomu např. ŠVESTKA, Jiří, DVOŘÁK, Jan, FIALA, Josef a kol. Občanský zákoník. Komentáŕ. Svazek III. [Systém ASPI] Praha: Wolters Kluwer ČR, 2014 [cit. 2020-03-14]. Komentář k § 1310.

50 § 1317 obč. zák.
} 
Pokud oproti tomu budou jako zástava užity přímo jednotky kryptoměny, tyto obtíže odpadnou. Zástavní dlužník převede smluvený počet jednotek ze své adresy na adresu zástavního dlužníka nebo třetí osoby ve smyslu $\S 1318$ obč. zák. Po splatnosti zajištěného dluhu se pak zástavní věřitel uspokojí zpơsobem dohodnutým se zástavcem či zástavním věřitelem, například prodejem jednotek na některé kryptoměnové burze.

Jednotky kryptoměny, resp. adresa, na níž budou v době smrti zůstaviteli zapsány, budou způsobilé tvořit pozůstalost. ${ }^{51}$ Dědic ale nebude moci nabýt jednotky kryptoměny bez adresy, protože bez ní v podstatě neexistují. Měl by tedy nabýt kryptoměnovou adresu. K dispozicím $\mathrm{s}$ jednotkami $\mathrm{k}$ ní náležejícím ale bude třeba zároveň znát soukromý a veřejný klíč k této adrese. Pokud tuto znalost mít nebude, bude pro něj adresa naprosto bezcenná. To platí i pro zdědění hardwarové peněženky, v jejímž případě bude dispozici s jednotkami třeba potvrdit heslem, pinem nebo jiným zpo̊sobem, bez nichž k žádnému převodu jednotek nedojde.

Dědická daň byla s účinností od 1. 1. 2014 zrušena. Nebude tedy $\mathrm{v}$ uvedeném případě docházet $\mathrm{k}$ tomu, že by dědic nabyl adresu $\mathrm{s}$ určitým počtem jednotek, musel by ale z jejího nabytí zaplatit dědickou daň, a to i navzdory tomu, že by pro něj neměla žádnou hodnotu, když by s jednotkami nemohl jakkoliv disponovat.

Dříve dosažené závěry také naráží na to, že internet $\mathrm{v}$ podstatě nemá hranice a složitě se $\mathrm{v}$ přeshraničních sporech určuje rozhodné právo. $\mathrm{V}$ jeho prostoru je oslaben význam polohy a vzdálenosti, do styku přicházejí různé osoby bez ohledu na jejich aktuální místní příslušnost. ${ }^{52}$ To bude platit i v prostředí protokolu blockchain, který má - alespoň v případě velkých kryptoměnových sítí - skutečně globální charakter. Také to, že české právo považuje kryptoměnu za věc, ještě neznamená, že tento závěr bude mít nějaký význam u přeshraničního sporu, ve kterém bude užito jako rozhodného práva jiného právního řádu, který věc v právním smyslu bude chápat odlišněji.

51 Srov. § 1475 odst. 2 a § 495 obč. zák.

52 KASL, František. Blockchain, společenská smlouva digitálního věku? Revue pro právo a technologie. 2018, č. 17, s. 6. 


\section{VÝSLOVNÁ ÚPRAVA?}

Je možné klást otázku, zda je na místě prostřednictvím soukromého práva výslovně regulovat kryptoměny. Autoři knihy o Bitcoinu uvádějí, že „je obtížné psát knihu o něčem, co se mění každý den. Bitcoin je nový a je to živoucí ekosystém, kde dochází neustále k inovacím. “53 Touto citací lze v zásadě na předloženou otázku jednoduše odpovědět.

Obecně platí, že technologie vždy byly a budou o krok napřed před právní úpravou. Tomu odpovídá neschopnost českého zákonodárce účinným zpơsobem speciálně upravit například platformy typu UBER, Airbnb a jiné či alespoň zavést jejich zákonnou definici.

Platí-li tedy, že právo bude vždy informační technologie a jejich vývoj schopno stíhat víceméně neúspěšně, je vhodnější užívat při jejich konfrontaci s právem spíše obecné instituty než zavádět nové. I kupřríkladu otázky spojené s vysoce specifickou oblastí doménových jmen lze řešit bez speciální úpravy. ${ }^{54}$ Například Telec pak vyzývá, abychom se pokusili „na nové jevy $v$ právu včetně otázek informačních a komunikačních technologií nahlížet 'starýma' civilistickýma očima. “55

Těmto závěrům odpovídá i výše řečené o projevech virtualizace ve vývoji informačních technologií a v oboru práva informačních technologií. Zároveň to, že se v oboru práva informačních technologií nezavádí nějaké zásadní nové instituty, o něm ale nevypovídá nic negativního. I přes to, že informační technologie sice nepřinesly nic zásadně nového, Polčák uvádí, že rozkrytí jejich filozofické podstaty obohatilo právní teorii, filozofii a zprostředkovaně i právní praxi. ${ }^{56}$

$\mathrm{Na}$ druhou stranu je ale nutné právo některým aspektům technologického rozvoje a jeho směřování otevřít. Jen jako jeden z př́ikladů z mnoha lze zmínit Německo, které v září 2019 přijalo strategii využití

53 STROUKAL, Dominik. SKALICKÝ, Jan. Bitcoin a jiné kryptopeníze budoucnosti. Praha: Grada. 2018. s. 22.

54 MACGREGOR PELIKÁNOVÁ, Radka. (Ne)jasné pojetí doménových jmen a jejich režimu V novém občanském zákoníku. Rekodifikace \& Praxe, 2015, č. 3(1).

55 TELEC, Ivo. Poznámky k internetu a proměnám práva. Právní rozhledy. 2013, č. 12.

56 POLČÁK, R. Právo informačních technologií. Praha: Wolters Kluwer ČR, 2018, s. 9 
blockchainu a jeho potenciálu $\mathrm{k}$ postupu digitální transformace $\mathrm{e}^{57}$ anebo záměr, aby ve Spojených státech amerických byly kryptoměny, jejichž hodnota je vázána na fiat měnu, považovány za cenné papíry ${ }^{58}$. Existující regulaci již má také např́ḱlad Lichtenštejnsko, jehož parlament 3. 10. 2019 s účinností od 1. 1. 2020 přijal zákon upravující užití tokenů založených na protokolu blockchain. ${ }^{59}$

V souladu s uvedeným závěrem o preferenci užití obecných institutů bylo v předchozím textu ukázáno, že na kryptoměny lze aplikovat některá ustanovení občanského zákoníku. Autor textu si je nicméně vědom limitů tohoto závěru, jelikož právo $\mathrm{v}$ prostředí protokolu blockchain do jisté míry tahá za kratší konec. Ačkoliv na ně lze aplikovat některá zákonná ustanovení, veškeré dispozice $s$ jednotkami kryptoměny jsou limitovány pravidly protokolu blockchain a asymetrickou kryptografií, nikoliv právem. Formálně sice může být uživatel kryptoměny vlastníkem jejích jednotek, ale např́íklad bez znalosti soukromého kryptografického klíče ke konkrétní adrese s nimi nebude schopen jakkoliv nakládat. Na této skutečnosti nezmění nic ani rozhodnutí soudu ani zákon. Toto bylo $\mathrm{v}$ textu článku ukázáno na institutech zástavního a dědického práva.

Svět mimo internet, resp. mimo kyberprostor je primárně řízen přírodními zákony. Člověkem vydaný zákon tak bude např́ílad těžko úspěšně předepisovat, kdy má a nemá sněžit. Co je a není možné v rámci protokolu blockchain je naproti tomu určeno jeho pravidly. Ta sice nejsou neměnná a vpř́padě blockchainů typu Bitcoin je lze změnit za předpokladu akceptace nových pravidel většinou uživatelů. ${ }^{60}$ Na rozdíl od přírodních zákonů budou tedy uživatelé schopni zákonitosti konkrétního

57 Bundesmisterium der Finanzen. German Government Adopts Blockchain Strategy. [online]. Dostupné z: https://www.bundesfinanzministerium.de/Content/EN/Standardartikel/ Topics/Financial_markets/Articles/2019-09-18-Blockchain.html. [cit. 2019-11-9].

${ }^{58}$ Discussion Draft: Stablecoins are Securities Act of 2019. [online] https://financialservices.house.gov/uploadedfiles/bills-116pih-ssa.pdf. [cit. 2019-11-16].

59 Regierung des Fürstentums Liechtenstein. Landtag stimmt dem Blockchain-Gesetz einstimmig $z u$. [online] https://www.regierung.li/de/mitteilungen/222957/?typ = news [cit. 2019-11$10]$.

${ }^{60}$ KASL, František. Blockchain, společenská smlouva digitálního věku? Revue pro právo a technologie. 2018, č. 17. s. 11. 
blockchainu do jisté míry změnit. To ale nic nevypovídá o vymahatelnosti práva a soudních rozhodnutí $\mathrm{v}$ jeho rámci, resp. o možnosti jeho zásadní zákonné regulace. Nezbývá tedy zřejmě než pokrčit rameny a konstatovat "code is law". ${ }^{61}$

\section{ZÁVĚR}

Kryptoměnou text rozumí druh virtuální měny, jejíž vlastnictví se prokazuje pouze prostřednictvím kryptografie aje evidováno prostřednictvím protokolu blockchain, bez nějž není možné s jednotkami kryptoměny jakkoliv disponovat.

$\mathrm{Na}$ vztahu mezi uživatelem převádějícím jednotky kryptoměny a těžařem bylo ilustrováno užití ustanovení občanského zákoníku o nabídce a akceptaci. Bylo konstatováno, že z pohledu občanského práva lze kryptoměny podřadit pod definici věci ve smyslu § 489 obč. zák., a to věc nehmotnou, movitou a podle názoru autora zastupitelnou. Kryptoměny však nelze v současné chvíli považovat za cenný papír ani zaknihovaný cenný papír tak, jak je chápe český právní řád.

Nakládání s jednotkami kryptoměny je však spíše než právem omezeno pravidly protokolu blockchain. Veškeré dispozice $s$ nimi jsou závislé na znalosti soukromého kryptografického klíče ke konkrétní adrese, interakci s ostatními uživateli a zákonitostmi sítě. Bude sice možné kryptoměnovou peněženku, resp. adresu zastavit, vzhledem $\mathrm{k}$ zákonitostem protokolu blockchain to ale bude problematické. Stejně tak bude možné kryptoměnovou adresu zdědit. Bez znalosti soukromého klíče však dědic $\mathrm{z}$ takového dědictví př́liš nadšený zřejmě nebude, protože $s$ jednotkami nebude schopný disponovat, tedy je ani prodat za fiat měnu.

Klasifikace jednotek kryptoměny jako věci má rovněž své limity $\mathrm{s}$ ohledem na problematické určení rozhodného práva $\mathrm{v}$ př́padných sporech s mezinárodním prvkem.

Autor textu také souhlasí se závěrem, že je v případě informačních technologií spíše vhodnější užívat obecné právní instituty než zavádět nové.

${ }^{61}$ LESSIG, Lawrence. Code: Version 2.0. New York: Basic Books, 2006. 
Pro protokol blockchain a kryptoměny to platí také. Na druhou stranu je ale vhodné umožnit jejich širší užití tak, jak to činí některé právní řády.

\section{SEZNAM POUŽITÝCH ZDROJŮ}

[1] BENTOV, Iddo et al. Proof of activity: extending bitcoin's proof of work via proof of stake. In Proceedings of the ACM SIGMETRICS 2014 Workshop on Economics of Networked Systems, NetEcon 2014: [online]. Dostupné z: https://eprint.iacr.org/2014/452.pdf [cit. 2020-01-20].

[2] Bundesmisterium der Finanzen. German Government Adopts Blockchain Strategy. [online]. Dostupné z: https://www.bundesfinanzministerium.de/Content/EN/Standardartikel/Topics/ Financial_markets/Articles/2019-09-18-Blockchain.html. [cit. 2019-11-9].

[3] DĚDIČ, Jan. ŠOVAR, Jan. MIKULA, Ondřej. Proč podle českého soukromého práva nelze uvažovat o (ICO) tokenech jako o cenných papírech. Právní rozhledy. 2018, č. 15-16, s. 554556.

[4] Discussion Draft: Stablecoins are Securities Act of 2019. [online] https://financialservices.house.gov/uploadedfiles/bills-116pih-ssa.pdf. [cit. 2019-11-16].

[5] DRAŠTÍK, Alexandr. FREMR, Robert. DURDÍK, Tomáš a kol. Trestní zákoník. Komentář. [Systém ASPI]. Wolters Kluwer [cit. 2019-03-20].

[6] DVOŘÁK, Jan. ŠVESTKA, Jiří. ZUKLÍNOVÁ, Michaela a kol. Občanské právo hmotné. Svazek I. Díl první. Obecná část. 2. Aktualizované a doplněné vydání. Praha: Wolters Kluwer ČR, 2016.

[7] ELEK, Štefan; LIŠKA, Petr; MAREK, Karel. Bankovní obchody. [Systém ASPI] Wolters Kluwer [cit. 2020-03-14].

[8] HOBZA, Martin. ICO a tokeny optikou práva kapitálového trhu: mohou být tokeny investičními cennými papíry? Bulletin advokacie. 2019, č. 3, s. 41-46.

[9] International Telecommunication Union. Percentage of Individuals using the Internet. [online] Dostupné z: https://www.itu.int/en/ITU-D/Statistics/Documents/statistics/2018/

Individuals_Internet_2000-2017_Dec2018.xls, [cit. 2019-03-20].

[10] KASL, František. Blockchain, společenská smlouva digitálního věku? Revue pro právo a technologie. 2018, č. 17.

[11] KOUBSKÝ, Petr. Před deseti lety vymyslel Satoshi Nakamoto peníze, kterými si budou navzájem platit roboti. Deník $N$, [online]. Dostupné z: https://denikn.cz/11417/pred-desetilety-vymyslel-satoshi-nakamoto-penize-kterymi-si-budou-navzajem-platit-roboti [cit. 2019-0217].

[12] LÁNSKÝ, Jan. Kryptoměny. 1. vydání. Praha: C. H. Beck, 2018.

[13] LESSIG, Lawrence. Code: Version 2.0. New York: Basic Books, 2006.

[14] LIŠKA, Petr. Účet, jednorázový vklad, akreditiv a inkaso v občanském zákoníku. [Systém ASPI]. Wolters Kluwer [cit. 2020-03-14]. 
[15] MAREK, Radan, JEŽEK, Václav. Cenné papíry v novém občanském zákoníku. 1. vydání. Praha: Nakladatelství C. H. Beck, 2013.

[16] MACGREGOR PELIKÁNOVÁ, Radka. (Ne)jasné pojetí doménových jmen a jejich režimu v novém občanském zákoníku. Rekodifikace \& Praxe, 2015, č. 3(1).

[17] Metodický pokyn č. 2 Finančního analytického útvaru Ministerstva financí ze dne 16. záŕí 2013, Č.j.: MF-86584/2013/24.

[18] NAKAMOTO, Satoshi. Bitcoin: A Peer-to-Peer Electronic Cash System, [online] Dostupné z: https://bitcoin.org/bitcoin.pdf [cit. 2019-03-20].

[19] NĚMEC, Libor. TORNOVÁ, Jarmila., K právní regulaci kryptoměn. Díl II. Právní rádce. roč. 2018 , č. 7.

[20] Obchodování s bitcoiny / Je kobchodování sbitcoinynebo $\mathrm{k}$ jejichsměně potřebné povolení ČNB? [online]. Dostupné z: https://www.cnb.cz/miranda2/export/sites/www.cnb.

cz/cs/faq/stanoviska_a_odpovedi/pdf/obchodovani_s_bitcoiny.pdf [cit. 2019-03-17].

[21] PAULY, Jan. Teoretické a legislativní základy cenných papírů. [Systém ASPI]. Wolters Kluwer. 2016. [cit. 2020-03-14].

[22] POLČÁK, Radim, KASL, František, LOUTOCKÝ, Pavel. MÍŠEK, Jakub, STUPKA, Václav. Virtualizace právních vztahů a nové regulatorní metody v pozitivním právu. Právník, AV ČR, Ústav státu a práva, 2019, roč. 2019, č. 1, s. 86-98.

[23] Proof of Work. Investopedia. [online]. Dostupné z: https://www.investopedia.com/ terms/p/proof-work.asp, [cit. 2020-01-20].

[24] Proof of Stake. Investopedia. [online]. Dostupné z: https://www.investopedia.com/ terms/p/proof-stake-pos.asp, [cit. 2020-01-20].

[25] Regierung des Fürstentums Liechtenstein. Landtag stimmt dem Blockchain-Gesetz einstimmig zu. [online] https://www.regierung.li/de/mitteilungen/222957/?typ=news [cit. 2019-11-10].

[26] SPÁČIL, Jiří a kol. Věcná práva. Věcná práva, katastr nemovitostí a správa cizího majetku. Praha C. H. Beck, 2018.

[27] STROUKAL, Dominik. SKALICKÝ, Jan. Bitcoin a jiné kryptopeníze budoucnosti. Praha: Grada. 2018.

[28] SZOSTOK, David. Cenný papír a zaknihovaný cenný papír jako věc v právním smyslu, Soukromé právo, 2016, č. 11, s 4 a násl.

[29] ŠVESTKA, Jiř́i, DVOŘÁK, Jan, FIALA, Josef a kol. Občanský zákoník. Komentář. Svazek I. Praha: Wolters Kluwer ČR, 2014.

[30] ŠVESTKA, Jiří, DVOŘÁK, Jan, FIALA, Josef a kol. Občanský zákoník. Komentářr. Svazek III. Praha: Wolters Kluwer ČR, 2014.

[31] TELEC, Ivo. Poznámky k internetu a proměnám práva. Právní rozhledy. 2013, č. 12.

[32] TRÁVNíK, Pavol. Bitcoin v českém právu, [online]. Dostupné z https://medium.com/@ 
pavol.travnik/bitcoin-v-českém-právu-308a82c78ebf [cit. 2019-07].

[33] VÍTEK, Jindřich. Právní úprava cenných papírů v občanském zákoníku. Obchodní právo, 2012, č. 12.

Toto dílo lze užít v souladu s licenčními podmínkami Creative Commons BY-SA 4.0 International (http://creativecommons.org/licenses/by-sa/4.0/legalcode). 